\title{
Rehabilitated sea turtles tend to resume typical migratory behaviors: satellite tracking juvenile loggerhead, green, and Kemp's ridley turtles in the northeastern USA
}

\author{
Nathan J. Robinson ${ }^{1,2, *}$, Kayla Deguzman ${ }^{2}$, Lisa Bonacci-Sullivan ${ }^{3}$, \\ Robert A. DiGiovanni Jr. ${ }^{4,5}$, Theodora Pinou ${ }^{2}$ \\ ${ }^{1}$ Fundación Oceanogràfic, Ciudad de Las Artes y las Ciencias, Valencia 46013, Spain \\ ${ }^{2}$ Western Connecticut State University, Danbury, Connecticut 06810, USA \\ ${ }^{3}$ New York State Department of Environmental Conservation, Albany, New York 12233, USA \\ ${ }^{4}$ Riverhead Foundation for Marine Research and Preservation, Riverhead, New York 11901, USA \\ ${ }^{5}$ Atlantic Marine Conservation Society, Hampton Bays, New York 11946, USA
}

\begin{abstract}
Wildlife rehabilitation programs are widely employed for many endangered marine species and can serve as engaging platforms for environmental outreach. However, their effectiveness at supporting populations in the wild depends on whether rescued animals can survive and reproduce after being released. Here, we assessed whether cold-stunned juvenile sea turtles resumed typical migratory and diving behaviors after rehabilitation. We deployed satellite transmitters onto 7 rehabilitated loggerhead turtles Caretta caretta, 12 green turtles Chelonia mydas, and 12 Kemp's ridley turtles Lepidochelys kempii released around Long Island, New York, USA. Of these 31 turtles, 30 were tracked long enough to determine their migratory movements. The majority $(83 \%)$ left Long Island before local waters dropped below $14^{\circ} \mathrm{C}$ and avoided being coldstunned. Most individuals followed migratory routes previously reported for each of the 3 species, migrating to either coastal waters off the southeast USA or oceanic waters of the Gulf Stream. Rehabilitated turtles of each species also resumed typical diving patterns. Four of the remaining 5 turtles that did not migrate away from Long Island were likely cold-stunned again. Overall, most cold-stunned sea turtles tend to resume typical migratory and diving behavior post-rehabilitation.
\end{abstract}

KEY WORDS: Wildlife Rehabilitation · Telemetry $\cdot$ Marine Turtles $\cdot$ Conservation $\cdot$ Long Island Sound · Animal Rescue

\section{INTRODUCTION}

Wildlife rehabilitation programs are widely employed for many endangered marine species (Mignucci-Giannoni 1998, Feck \& Hamann 2013). These programs treat debilitated, injured, or diseased animals until they are healthy enough to be released back into the wild (Vogelnest 2008). Yet even after treatment, rehabilitated animals may not successfully resume 'natural' behaviors, such as feeding or breeding, and might not survive in the

\footnotetext{
${ }^{*}$ Corresponding author: nathanjackrobinson@gmail.com
}

long-term or be reintegrated into wild breeding populations (Innis et al. 2019a). Knowledge of how rehabilitated animals behave post-release is therefore central to evaluating the efficacy of rehabilitation programs for wildlife conservation (Guy et al. 2013, Caillouet et al. 2016). This is especially relevant for sea turtles, as there are numerous rehabilitation programs for this taxon worldwide (Ullmann \& Stachowitsch 2015, Innis et al. 2019a) and these programs are often associated with considerable financial costs (Flint et al. 2017).

(C) The authors 2020. Open Access under Creative Commons by Attribution Licence. Use, distribution and reproduction are unrestricted. Authors and original publication must be credited. 
The northeastern coast of the USA hosts a network of sea turtle rehabilitation centers that primarily focus on loggerhead turtles Caretta caretta, green turtles Chelonia mydas, and Kemp's ridley turtles Lepidochelys kempii (Innis et al. 2019a). These 3 species are seasonally found as far north as Long Island Sound (LIS), New York, and Cape Cod, Massachusetts (Morreale et al. 1992, Still et al. 2005, Innis et al. 2009). However, when water temperatures drop towards the end of the year, they migrate away from this region in search of warmer waters (Morreale \& Standora 2005, Hawkes et al. 2007, Williard et al. 2017). Turtles that do not migrate run the risk of being cold-stunned when local temperatures begin to drop. Cold-stunning is a hypothermic reaction that occurs when sea turtles or other reptiles are exposed to abnormally cold temperatures for prolonged periods of time. For green turtles, cold-stunning often occurs when sea surface temperatures (SSTs) fall below $10^{\circ} \mathrm{C}$ (Roberts et al. 2014), while the threshold is between 7 and $10^{\circ} \mathrm{C}$ for Kemp's ridley turtles and $5-9^{\circ} \mathrm{C}$ for loggerhead turtles (Morreale et al. 1992, Still et al. 2005). The primary symptom of cold-stunning is an acute lethargy, which is often accompanied by shock, pneumonia, and eventually death (Innis et al. 2009, 2019b, Keller et al. 2012). Consequently, cold-stunned turtles are often found floating at-sea or stranded on beaches (Witherington \& Ehrhart 1989). Cold-stunned turtles likely have little chance of surviving in the wild, yet they can recover after receiving appropriate treatment in a rehabilitation center (Shaver et al. 2017). Rehabilitated individuals are generally released back into the wild (Innis et al. 2019a).

Satellite transmitters are commonly used tor monitoring sea turtles after they have been released from rescue centers (e.g. Mestre et al. 2014, Flint et al. 2017, Robinson et al. 2017). These devices remotely relay information on animals' migration patterns over a period of months to years. Satellite transmitters can also be fitted with depth sensors to record data on a turtle's diving patterns, which can be used as a proxy to assess feeding behavior (Hochscheid 2014, Freitas et al. 2018). Deploying satellite transmitters onto rehabilitated animals can therefore be an effective method to assess if these animals are able to survive post-release (Mestre et al. 2014). In addition, by comparing the movements and diving patterns of rehabilitated animals to wild-caught conspecifics, it is possible to determine if rehabilitated individuals resume typical behaviors (Cardona et al. 2012). Such insight can, in turn, support the idea that rehabilitated individuals can be reincorporated into wild breeding populations.
Typical migratory behavior for the loggerhead, green, and Kemp's ridley turtles that seasonally inhabit the waters off the northeastern USA involves heading into warmer waters before local temperatures drop with the onset of winter (Hawkes et al. 2011, Williard et al. 2017). The migratory movements of all 3 species are notably similar and tend to involve a southerly migration to coastal habitats on the southeast US coastline or an easterly migration into the offshore waters of the Gulf Stream (Gitschlag 1996, Morreale \& Standora 2005, Hawkes et al. 2007, 2011, Williard et al. 2017). In contrast, the diving behavior and foraging preferences differ between species. Loggerhead and green turtles both tend to be benthic feeders; however, loggerhead turtles feed largely on hard-shelled invertebrates (Burke et al. 1993) whereas green turtles feed largely on seagrass and algae (Williams et al. 2014, Gillis et al. 2018). Kemp's ridley turtles tend to feed on a mix or benthic and pelagic crustaceans, fish, and molluscs (Burke et al. 1993, 1994).

Here, we deployed satellite transmitters onto juvenile green, loggerhead, and Kemp's ridley turtles after being released from rehabilitation centers in Long Island, New York, USA. Using data generated by the transmitters, we aimed to answer 4 major questions. (1) Do rehabilitated cold-stunned green, loggerhead, and Kemp's ridley turtles released on the northeastern coast of the USA resume typical seasonal migrations and thus avoid being cold-stunned when local water temperatures drop in winter? (2) Are the long-distance movement patterns of rehabilitated sea turtles comparable to those of wild individuals? (3) Are the diving patterns of rehabilitated sea turtles comparable to wild-caught individuals in similar habitats? (4) How do movements, diving patterns, and thermal preferences differ among rehabilitated loggerhead, green, and Kemp's ridley turtles?

\section{MATERIALS AND METHODS}

\subsection{Turtle rehabilitation, release, and satellite tracking}

We deployed satellite transmitters onto 31 turtles rehabilitated at the New York Marine Rescue Center between 2007 and 2015 (see Table 1). Of these 31 turtles, 7 were loggerhead turtles (straight carapace length: 25.5-69.9 cm), 12 were green turtles (25.3$58.9 \mathrm{~cm})$, and 12 were Kemp's ridley turtles (18.2$58.3 \mathrm{~cm})$. These turtles, which had been coldstunned but showed no injuries other than superficial 
bruising and shallow lacerations, were encountered in November or December during routine patrols along known sea turtle stranding sites or by opportunistic sightings by the public. We specifically chose individuals for this study that were admitted to the rehabilitation program due to cold-stunning events and had no external injuries, as injuries may further limit the animals' ability to readapt to life in the wild.

The turtles were retained between 2 and $575 \mathrm{~d}$ at the New York Marine Rescue Center until they were actively eating, swimming, no longer dependent on medication, and had passed a medical review. At this point, we attached satellite transmitters to each of turtle using epoxy (see Coyne et al. 2008). All transmitters were programmed to relay location data via the ARGOS system continually for the first month of deployment and then switch to a 1-day-on/1-day-off duty cycle. Three different types of satellite transmitters were utilized: Mk10, Splash, and SPOT5 units (Wildlife Computers) (see Table 1). Of the 31 satellite-tracked turtles, 27 were released on the southern coast of Long Island and into the Atlantic Ocean and 4 were released on northern coast and into LIS.

\subsection{Movement analysis}

To delete spurious locations indicating an unrealistic movement speed from the raw location data, we incorporated a speed filter of $>100 \mathrm{~km} \mathrm{~d}^{-1}$. Subsequently, we used a hierarchical Bayesian state space model (BSSM) to smooth the tracks and provide daily location estimates (see Jonsen et al. 2013). The BSSM was run with 2 chains for 10000 Markov chain Monte Carlo samples with a 7000 burn-in (thin =5). When gaps in the raw location data were not available for over 10 consecutive days, we excluded the modeled locations between this period to prevent the BSSM from creating unrealistic tracks using insufficient data.

\subsection{Diving analysis}

The MK10 and SPLASH transmitters were deployed on 6 loggerhead, 4 green, and 6 Kemp's ridley turtles and were programmed to record depth every $10 \mathrm{~s}$. These data were processed internally and opportunistically relayed as binned maximum dive-depth and dive-duration summaries. As dive bins were not standardized between transmitters, we only used a subset of the 14 available bins that were kept constant between all transmitters. The subset of the dive bins were $0,10,20,50,100$, and $>100 \mathrm{~m}$ for maximum dive depth and $0,6,12,18$, and $>18$ min for dive duration. We defined a dive as any period when the dive sensor descended below $2 \mathrm{~m}$ depth. We compared dive bins both between the 3 turtle species as well as between individuals occupying coastal habitats of depths $<200$ $\mathrm{m}$ and those in offshore habitats of depths $>200 \mathrm{~m}$.

\subsection{Environmental features}

Turtle locations were overlaid onto spatially referenced data sets of bathymetry and SST. Bathymetry data at a spatial resolution of $0.017^{\circ}$ were provided by the global relief model, ETOPO1, available from the National Geographic Data Center (www.ngdc.noaa. gov/mgg/global/). Daily SST values at a spatial resolution of $0.25^{\circ}$ were obtained via the AVHRR platform (AVHRR_OI-NCEI-L4-GLOB-v2.0) available from NASA's Physical Oceanography Distributed Active Archive Center (https://podaac.jpl.nasa.gov/). To characterize the thermal conditions experienced by the tracked turtles, we generated frequency histograms to illustrate the range of SSTs experienced by each species. To assess whether the distributions of these histograms were equivalent for each species, we used Kolmogorov-Smirnov 2-sample tests in $\mathrm{R}$ v.3.5.2 (www.r-project.org) using $\alpha=0.05$.

\section{RESULTS}

\subsection{Movement patterns}

The 31 transmitters generated 3886 daily locations, with a range of 6-338 active transmitting days and averaging 125.4 daily locations transmitter ${ }^{-1}$ (Table 1). When including periods when no daily locations were available for over 10 consecutive days, the average tracking duration further increased to $137.9 \mathrm{~d}$ turtle ${ }^{-1}$.

We collected at least $28 \mathrm{~d}$ of tracking data (Fig. 1) for all but one (LK5) of the 31 transmitters (that transmitter stopped relaying locations after just $6 \mathrm{~d}$ ). The 30 turtles that were tracked long enough to determine long-distance movement patterns all eventually migrated away from Long Island by 1 November (Fig. 2A-C) with the exception of 2 green (CM5, CM8) and 3 Kemp's ridley turtles (LK3, LK9, LK10) that remained within $100 \mathrm{~km}$ of their release location until their transmitters stopped. The final transmission from the 2 green turtles occurred on 23 November and 22 December and for the Kemp's ridley turtles on 23 August, 30 October, and 8 December. 
Table 1. Information on 31 satellite-tagged sea turtles released after being rehabilitated from cold-stunning events on Long Island, USA. ID: turtle identifier; tracking duration: time between release and date of final relayed location. Migratory behavior - 1: migration south into coastal habitats of North Carolina or Florida; 2: initial migration south to North Carolina, then offshore along the prevailing currents of the Gulf Stream; 3: immediate migration into offshore waters, eventually joining the prevailing currents of the Gulf Stream; N/A: insufficient tracking data

\begin{tabular}{|c|c|c|c|c|c|c|c|}
\hline Identifier & Species & $\begin{array}{c}\text { Straight } \\
\text { carapace length } \\
(\mathrm{cm})\end{array}$ & $\begin{array}{c}\text { Transmitter } \\
\text { model }\end{array}$ & $\begin{array}{l}\text { Time in } \\
\text { captivity } \\
\text { (d) }\end{array}$ & Release date & $\begin{array}{l}\text { Tracking } \\
\text { duration } \\
\text { (d) }\end{array}$ & $\begin{array}{l}\text { Migratory } \\
\text { behavior }\end{array}$ \\
\hline $\mathrm{CC} 1$ & Loggerhead & 56.5 & SPLASH & 85 & 6-Oct-2007 & 226 & 3 \\
\hline $\mathrm{CC} 2$ & Loggerhead & 69.6 & SPOT5 & 277 & 3-Aug-2006 & 195 & 1 \\
\hline $\mathrm{CC} 3$ & Loggerhead & 25.5 & MK10 & 315 & 17-Jul-2009 & 211 & 2 \\
\hline $\mathrm{CC} 4$ & Loggerhead & 61.5 & MK10 & 224 & 25-Jul-2009 & 251 & 1 \\
\hline CC5 & Loggerhead & 43.4 & MK10 & 236 & 27-Jul-2009 & 62 & 1 or 2 \\
\hline CC6 & Loggerhead & 33.8 & SPLASH & 342 & 6-Aug-2013 & 339 & 2 \\
\hline $\mathrm{CC} 7$ & Loggerhead & 50.9 & SPLASH & 255 & 10-Aug-2013 & 68 & 1 or 2 \\
\hline CM1 & Green & 58.9 & SPOT5 & 575 & 28-Jul-2007 & 47 & 2 \\
\hline CM2 & Green & 27.2 & SPOT5 & 308 & 7-Sep-2009 & 182 & 1 \\
\hline CM3 & Green & 27.5 & SPOT5 & 297 & 17-Sep-2008 & 43 & 1 or 2 \\
\hline CM4 & Green & 27.4 & SPOT5 & 2 & 26-Jul-2007 & 175 & 3 \\
\hline CM5 & Green & 37.5 & SPLASH & 300 & 15-Sep-2008 & 70 & N/A \\
\hline CM6 & Green & 25.3 & SPOT5 & 301 & 30-Sep-2008 & 84 & 1 \\
\hline CM7 & Green & 28.5 & SPLASH & 266 & 16-Aug-2008 & 277 & 1 \\
\hline CM8 & Green & 42.0 & SPOT5 & 277 & 11-Sep-2010 & 103 & N/A \\
\hline CM9 & Green & 31.3 & SPLASH & 241 & 6-Aug-2011 & 178 & 1 \\
\hline CM10 & Green & 26.6 & SPOT5 & 229 & 15-Jul-2011 & 326 & 3 \\
\hline CM11 & Green & 31.0 & SPLASH & 212 & 10-Jul-2012 & 76 & 1 or 2 \\
\hline CM12 & Green & 38.6 & SPOT5 & 254 & 9-Aug-2013 & 208 & 1 \\
\hline LK1 & Kemp's ridley & 33.0 & SPOT5 & 5 & 6-Oct-2007 & 71 & 1 or 2 \\
\hline LK2 & Kemp's ridley & 32.0 & SPOT4 & 284 & 16-Aug-2005 & 67 & 1 or 2 \\
\hline LK3 & Kemp's ridley & 31.1 & SPLASH & 291 & 22-Sep-2007 & 78 & $\mathrm{~N} / \mathrm{A}$ \\
\hline LK4 & Kemp's ridley & 29.3 & SPLASH & 239 & 10-Aug-2008 & 153 & 2 \\
\hline LK5 & Kemp's ridley & 18.2 & SPLASH & 376 & 26-Aug-2008 & 6 & N/A \\
\hline LK6 & Kemp's ridley & 34.3 & SPLASH & 290 & 20-Sep-2008 & 223 & 2 \\
\hline LK7 & Kemp's ridley & 25.5 & SPOT5 & 315 & $15-$ Oct- 2010 & 175 & 1 \\
\hline LK8 & Kemp's ridley & 58.3 & SPOT5 & 213 & 25-Aug-2011 & 183 & 1 \\
\hline LK9 & Kemp's ridley & 31.0 & SPLASH & 220 & 21-Jul-2012 & 34 & N/A \\
\hline LK10 & Kemp's ridley & 26.8 & SPOT5 & 229 & 21-Jul-2010 & 102 & N/A \\
\hline LK11 & Kemp's ridley & 38.4 & SPLASH & 233 & 27-Jul-2013 & 66 & 1 or 2 \\
\hline LK12 & Kemp's ridley & 27.1 & SPOT6 & 254 & 7-Sep-2015 & 28 & 1 or 2 \\
\hline
\end{tabular}

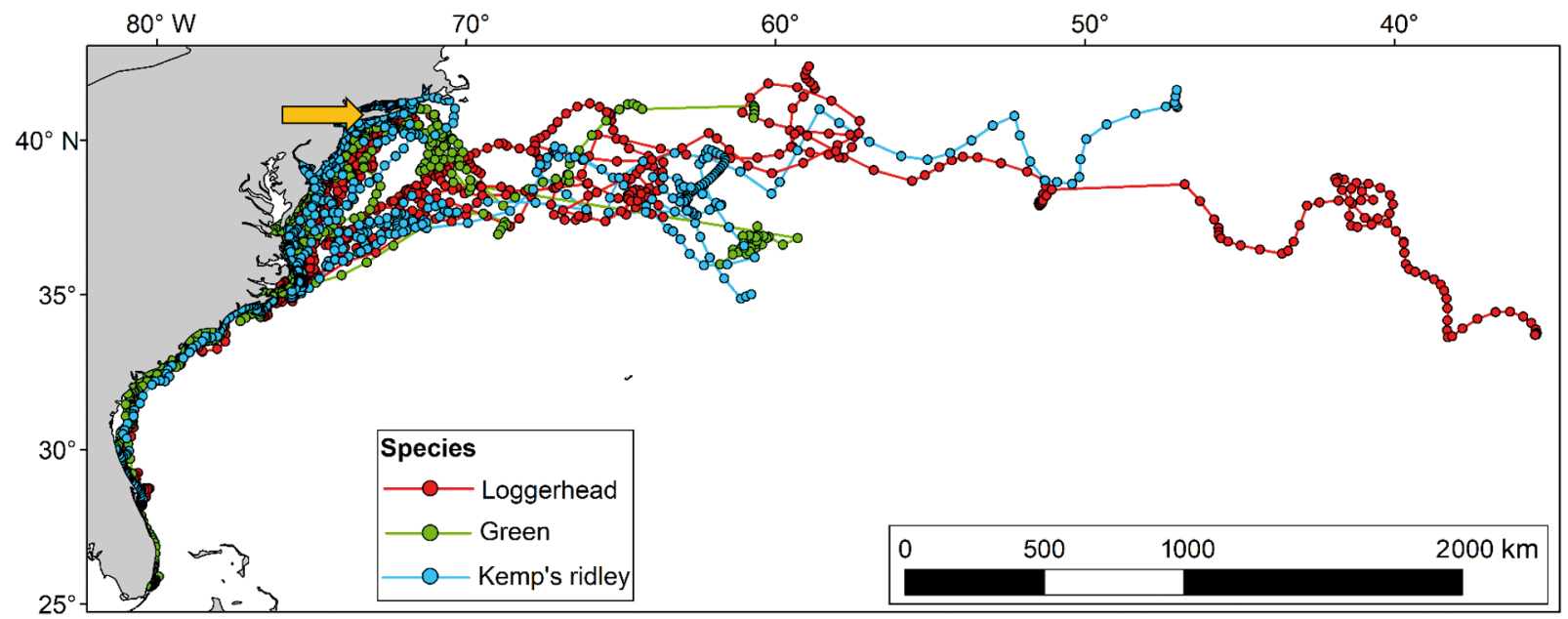

Fig. 1. Migratory routes of 31 satellite-tracked sea turtles, including 7 loggerhead, 12 green, and 12 Kemp's ridley turtles, released on the coast of Long Island, USA (yellow arrow) after being rehabilitated from cold-stunning. Colored dots represent 

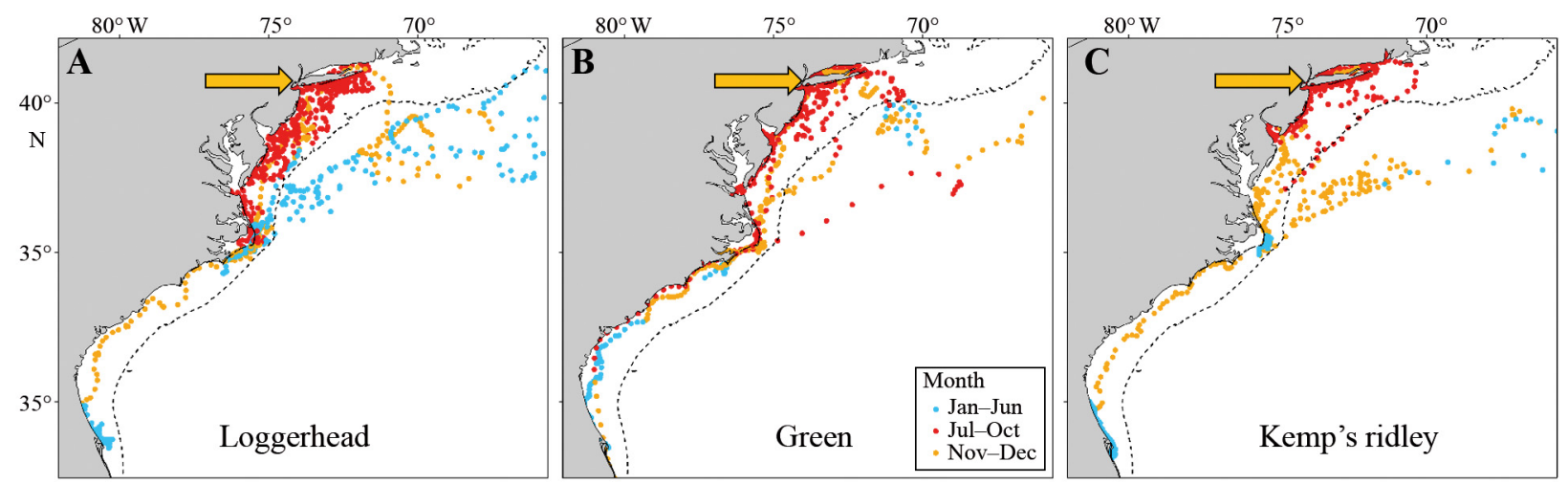

Fig. 2. Seasonal movement patterns of (A) 7 loggerhead, (B) 12 green, and (C) 12 Kemp's ridley turtles released on the coast of Long Island, USA (yellow arrow). Each dot represents a daily location; color reflects the date. Dashed black line: $200 \mathrm{~m}$ isoline, indicating the end of the continental shelf

The turtles that migrated away from Long Island all immediately began heading south with the exception of 2 loggerhead turtles (CC3, CC6), that initially made large $(>150 \mathrm{~km})$ looping movements off the southern shore of Long Island, and 2 Kemp's ridley turtles (LK2, LK6), that briefly migrated north to the shores of Massachusetts. Nevertheless, even these individuals eventually began more directed southerly migrations. The movements exhibited by turtles on their southerly migrations were categorized into one of 3 movement patterns (Figs. $1 \&$ S1 in the Supplement at www. int-res.com/articles/suppl/n043p133_supp.pdf): (1) a southerly migration along the US coastline into foraging areas in the Florida or North Carolina; (2) a southerly migration along the US coastline until North Carolina, at which point individuals followed the prevailing currents of the Gulf Stream into offshore waters; and (3) a southeast migration that took individuals immediately into offshore waters and eventually the offshore currents of the Gulf Stream. Understandably, it was not possible to discriminate between migratory pattern (1) and (2) when the transmitters stopped relaying before the individuals had reached North Carolina. There were no clear differences in the movement patterns of the 3 turtle species, and individuals of all species exhibited each of the 3 migratory patterns except for Kemp's ridley turtles, which never exhibited the third migratory pattern.

Those individuals following the first and second migratory patterns remained within $100 \mathrm{~km}$ of the US coast and in shallow waters of $<200 \mathrm{~m}$ for their entire southerly migration. Several individuals made brief stopovers of $<30 \mathrm{~d}$ in Raritan, Delaware, and Chesapeake Bay. The transmitters of 6 individuals (CC5, CM3, CM11, LK2, LK11, LK12) stopped transmitting while the turtles were migrating south to North Carolina, 4 individuals (CM7, CM12, LK7, LK8) migrated to coastal habitats in Florida, and the remaining 12 only migrated as far south as Pamlico Sound in North Carolina. Of these latter 12 , seven $(\mathrm{CC} 2, \mathrm{CC} 7, \mathrm{CM} 2$, CM6, CM9, LK1, LK8) remained in these waters until the end of their tracking duration, while the remaining 5 (CC3, CC6, CM1, LK4, LK6) eventually followed the prevailing currents of the Gulf Stream off North Carolina and into offshore waters. These offshore habitats were similar to those occupied by 1 loggerhead (CC1) and 2 green turtles (CM4, CM10) that followed the third migratory pattern and immediately headed into offshore habitats. This loggerhead turtle (CC1) exhibited the longest migration recorded in this study, traveling a total of $7339.5 \mathrm{~km}$ over its $226 \mathrm{~d}$ tracking duration. All individuals were either in offshore waters or in the waters off North Carolina by 1 December, with a single exception (CC3) that did not reach the waters off North Carolina until 20 January (Fig. 2A).

\subsection{Thermal conditions}

We extracted SST data for 3069 (79\%) of the 3886 locations from the 31 tracked turtles (Fig. S2). At the time of release, SSTs for all individuals ranged from $19.4-24.5^{\circ} \mathrm{C}$. Local SST within LIS tended to increase after release, peaking in early September between 22 and $26^{\circ} \mathrm{C}$ before dropping again. SST in LIS dropped to $\sim 14^{\circ} \mathrm{C}$ by 1 November (Fig. 3A-C), by which time most individuals had already migrated away from the area (Fig. 2A-C). From November onward, those individuals that migrated away from LIS rarely experienced temperatures below $\sim 14^{\circ} \mathrm{C}$, and in most instances temperatures even began to increase. Interestingly, those animals that migrated into offshore waters appeared to generally occupy warmer waters than their coastal counterparts (Fig. 3A-C).

Those 4 individuals (CM5, CM8, LK3, LK10) that remained in LIS beyond 30 October experienced 


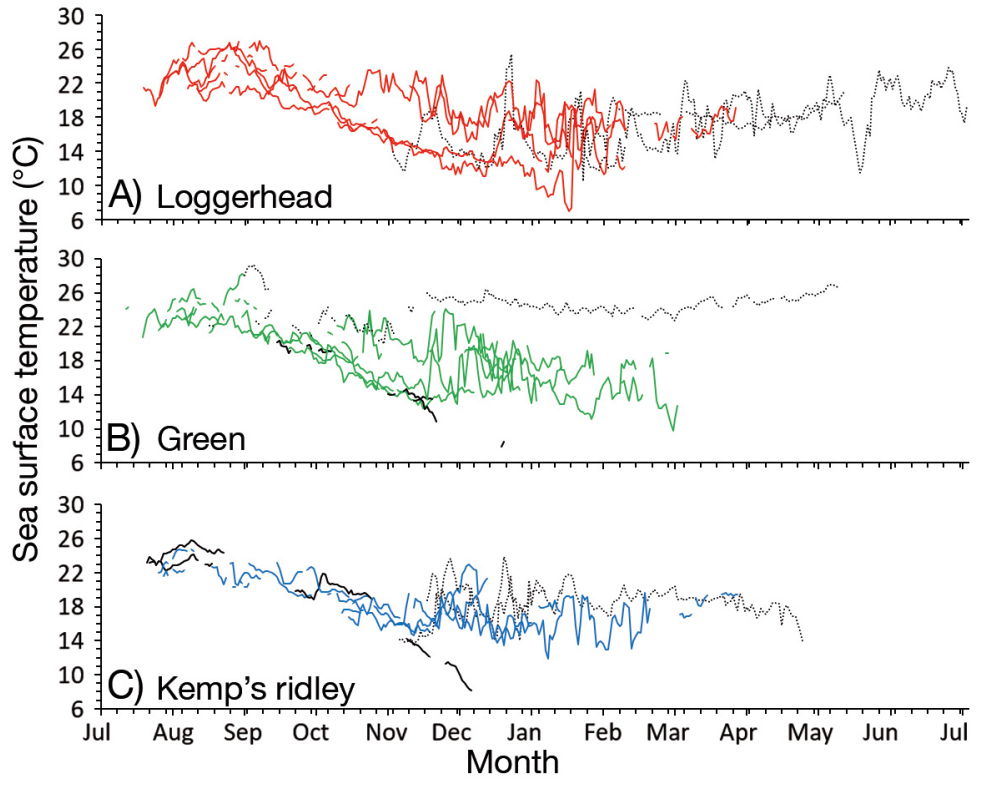

Fig. 3. Temporal patterns in local sea surface temperatures experienced by (A) 7 loggerhead, (B) 12 green, and (C) 12 Kemp's ridley turtles released on the coast of Long Island, USA. Colored lines: individuals that remained in coastal habitats $<200 \mathrm{~m}$ deep; dotted black lines: when individuals migrated into offshore waters $>200 \mathrm{~m}$ deep; solid black lines: individuals that never migrated away from Long Island Sound

SSTs that continued to fall below $14^{\circ} \mathrm{C}$. In contrast, those individuals that migrated away from LIS experienced SSTs values that remained far more constant. Only for a single loggerhead (CC3) was a drop in SST notably apparent. This loggerhead conducted several loops off the southern shore of Long Island before eventually migrating south on 15 December, over a month and a half after all other turtles had left Long Island. This animal experienced SSTs as low as $6.9^{\circ} \mathrm{C}$ during its migration south to North Carolina. Arriving on 21 January, this turtle then headed into offshore waters where SSTs increased to $16-20^{\circ} \mathrm{C}$ (Fig. 3A).

Kolmogorov-Smirnov 2-sample tests indicated that there were no statistically significant differences in the SST frequency distributions for each species (loggerhead vs. green: $K S=0.58, p=0.88$; loggerhead vs. Kemp's ridley: $\mathrm{KS}=0.78, \mathrm{p}=0.57$; green vs. Kemp's ridley: $\mathrm{KS}=0.59, \mathrm{p}=0.88$; Fig. 4). Nevertheless, some general differences between species were apparent. Loggerhead turtles tended to inhabit colder SSTs than green and Kemp's ridley turtles, with their frequency histograms exhibiting a roughly normal distribution that peaked between 16 and $18^{\circ} \mathrm{C}$. In addition, loggerhead turtles spent more time below $14^{\circ} \mathrm{C}$ $(15 \%)$ than either green turtles $(7 \%)$ or Kemp's ridley turtles $(3.6 \%)$. Green turtles inhabited warmer SSTs than either loggerhead or Kemp's ridley turtles, and their frequency histograms exhibited a positively skewed distribution peaking between 24 and $26^{\circ} \mathrm{C}$. Lastly, Kemp's ridley turtles inhabited intermediate SSTs, with their frequency histograms exhibiting a roughly normal distribution peaking between 18 and $20^{\circ} \mathrm{C}$. The 4 individuals that remained in LIS past 30 October, when local SSTs dropped below $14^{\circ} \mathrm{C}$, were not exhibiting normal migratory behavior and were likely eventually cold-stunned. We excluded them from this analysis as their SST profiles were unlikely to reflect that of a healthy animal.

\subsection{Dive behavior}

Frequency histograms for maximum dive-depth and dive duration revealed distinct patterns in diving behavior among species (Fig. 5A,B). When only considering turtles in coastal habitats, loggerhead turtles were generally the deepest diving of all 3 species, with $59 \%$ of dives occurring between 0 and $10 \mathrm{~m}, 22 \%$ between 10 and $20 \mathrm{~m}$, and $18 \%$ between 20 and $50 \mathrm{~m}$ (Fig. 5A). Kemp's ridley turtles tended to dive to intermediate depths, with $77 \%$ of dives occurring between 0 and $10 \mathrm{~m}, 12 \%$ between 10 and $20 \mathrm{~m}$, and $10 \%$ between 20 and $50 \mathrm{~m}$. Green turtles were the shallowest divers, with over $86 \%$ of all dives being between 0 and $10 \mathrm{~m}, 11 \%$ between 10 and $20 \mathrm{~m}$, and $2 \%$ between 20 and $50 \mathrm{~m}$. All species dove to depths of

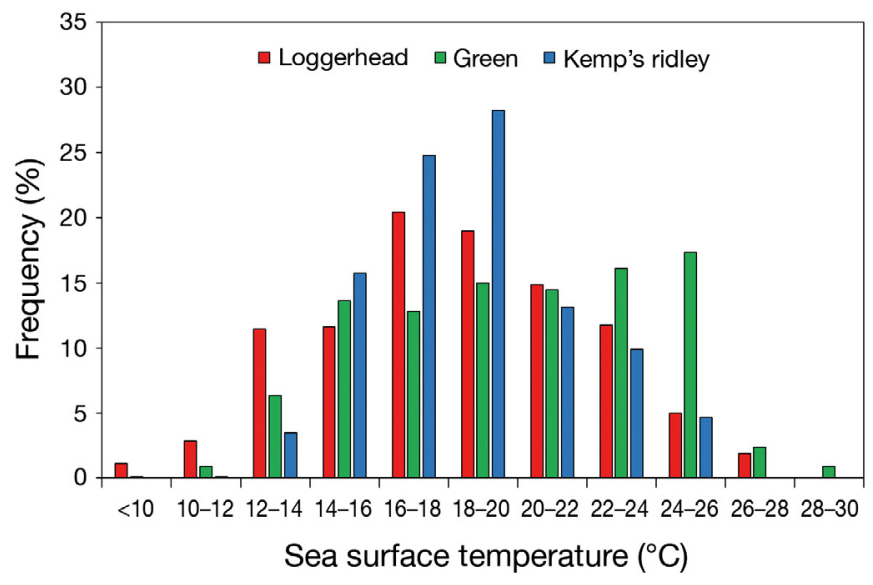

Fig. 4. Local sea surface temperatures experienced by 31 satellite-tracked sea turtles, including loggerhead, green, and Kemp's ridley turtles released on the coast of Long Island, USA 

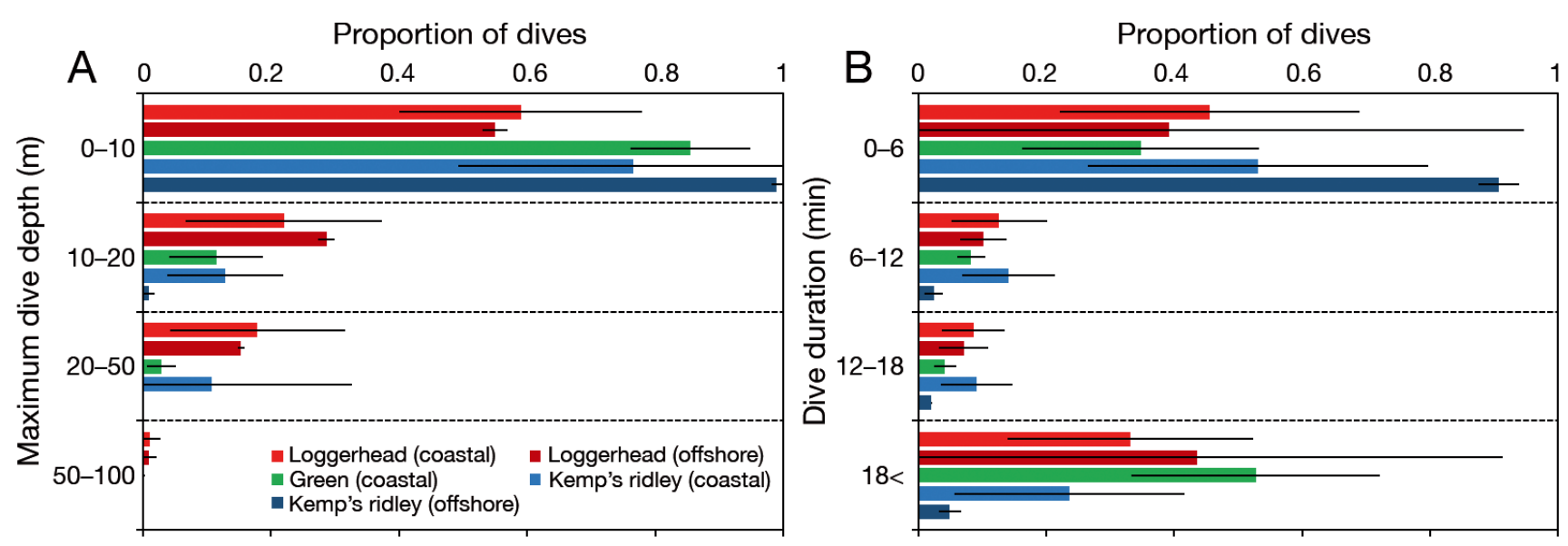

Fig. 5. Frequency histograms for binned (A) maximum dive depth and (B) dive duration for loggerhead turtles in coastal waters, loggerhead turtles in offshore waters, green turtles in coastal water, Kemp's ridley turtles in coastal waters, and Kemp's ridley turtles in offshore waters. Dives over $100 \mathrm{~m}$ were registered for all species but were in such low frequencies (0.01\%) that they were excluded from (A) for clarity. Error bars: $\pm 1 \mathrm{SD}$

50-100 $\mathrm{m}$ and even $>100 \mathrm{~m}$, but these constituted $<2$ and $<0.1 \%$ of dives respectively. Each species also exhibited a bi-modal distribution for dive duration, with peaks in diving between 0 and 6 min and $>18$ min and fewer dives of intermediate durations between $6-12$ or $12-18$ min (Fig. 5B). In summary, loggerhead turtles dove for intermediate durations, spending on average 46 and $33 \%$ of their time diving at durations of $0-6$ and $>18$ min respectively. Green turtles tended to take the longest dives, with 35 and $53 \%$ at $0-6 \mathrm{~min}$ and $>18 \mathrm{~min}$ respectively. Lastly, Kemp's ridley turtles conducted the shortest dives, spending $57 \%$ of their dives $<6$ min and only $21 \%$ of their dives over $18 \mathrm{~min}$. All species spent $<4 \%$ of dives between 6-18 $\mathrm{min}$.

When comparing the diving behavior of turtles in coastal habitats to their offshore counterparts, subtle differences were observed (Fig. 5A,B). Less than a $10 \%$ difference was observed in the proportion of dives in each dive bin, for both depth and duration, when comparing coastal loggerhead turtles to pelagic individuals. In contrast, offshore Kemp's ridley turtles dove for shorter durations and to shallower depths than their coastal counterparts. Over 99\% of all dives conducted by Kemp's ridley turtles while offshore were between 0 and $10 \mathrm{~m}$ and $90 \%$ of dives were $<6$ min in duration, while only $77 \%$ of the dives conducted by Kemp's ridley turtles in coastal waters were between 0 and $10 \mathrm{~m}$ and only $53 \%$ were $<6$ min. It was not possible to compare the diving behavior of green turtles in coastal and offshore habitats, as none of the transmitters deployed on green turtles that migrated offshore were programmed to relay dive data.

\section{DISCUSSION}

To assess the efficacy of wildlife rehabilitation programs as tools for conservation, we must ask the question: Do rescued animals survive and reproduce after being released back into the wild? (Tribe \& Booth 2003, Moore et al. 2007). Providing a definitive answer to this question often requires monitoring individuals for many years over wide geographic areas (Innis et al. 2019a). Nevertheless, short-term insights into survivorship and behavior of such animals post-release can be gleaned using satellite telemetry (Cardona et al. 2012, Mestre et al. 2014, Flint et al. 2017, Robinson et al. 2017). Here, we used satellite telemetry to assess how rehabilitated loggerhead, green, and Kemp's ridley turtles readapted to life in the wild. Our results indicated that, with a few exceptions, individuals from all 3 species survived and resumed typical migratory and diving behaviors after being released post-rehabilitation.

\subsection{Do rehabilitated sea turtles avoid repeat cold-stunning?}

We tracked 30 turtles long enough to determine their migratory behavior: $83 \%$ eventually migrated out of the waters off Long Island and into warmer waters in the southeastern USA or offshore waters of the Gulf Stream. The remaining 17\%, including 2 green turtles (CM5, CM8) and 3 Kemp's ridley turtles (LK3, LK9, LK10), remained in the waters of LIS until the end of their tracking duration. It is possible that these transmitters may have stopped responding due 
to mechanical or battery-life issues, and these turtles may have still migrated away from LIS. Alternatively, the transmitters may have stopped responding if these turtles died as a result of other causes such as predation, boat-strikes, or disease. However, considering that all but one of these turtles remained in LIS until past 30 October and that cold-stunning in LIS usually begins after the start of November (Morreale et al. 1992), we think the most plausible explanation is that at least these 4 individuals were eventually cold-stunned. Furthermore, these turtles were experiencing SSTs around $\sim 14^{\circ} \mathrm{C}$ and falling when their transmitters stopped responding, and cold-stunning is often correlated with SSTs around $10^{\circ} \mathrm{C}$ (Morreale et al. 1992, Roberts et al. 2014).

Numerous cold-stunned sea turtles are found on the shores of LIS each year (Burke et al. 1991, Morreale et al. 1992) and so it may not be surprising that some of the turtles tracked in this study could have also succumbed to cold-stunning. However, it is not yet clear if rehabilitated animals are more likely to be cold-stunned than their non-rehabilitated counterparts, as there are currently no accurate estimates on the proportion of wild turtles in LIS that are coldstunned each year. Species-specific susceptibility to cold-stunning after rehabilitation also needs to be elucidated further. While the present study provides some indication that only green and Kemp's ridley turtles were cold-stunned again after rehabilitation, larger sample sizes and direct evidence of cold-stunning of released turtles are required.

\subsection{Do rehabilitated sea turtles resume typical migratory behavior?}

We categorized the migratory patterns of the turtles tracked in this study into 3 distinct behaviors, involving either a southerly coastal migration, an initial coastal migration before heading into offshore waters, or migrating immediately into offshore waters. All 3 migratory patterns have been previously observed in wild-caught loggerhead, green, and Kemp's ridley turtles tagged throughout the eastern coast of the USA (Gitschlag 1996, Morreale \& Standora 2005, McClellan \& Read 2007, Williard et al. 2017, Winton et al. 2018), and this data provides support that rehabilitated turtles migrate and occupy habitats similar to non-rehabilitated individuals. In addition, these data confirm that the eastern coast of the USA and the oceanic waters of the Gulf Stream are important migratory habitats for loggerhead, green, and Kemp's ridley turtles.
Two loggerhead turtles (CC3 and CC6) displayed unusual behavior before departing on the more typical migratory route. Both individuals conducted large circuitous movements on the south coast of Long Island for several weeks before migrating south. In fact, one of these individuals (CC3) spent so long conducting these loops that it only began a directed movement south on 15 December (almost a month and half after all other turtles), experiencing SSTs as low as $6.9^{\circ} \mathrm{C}$. Interestingly, similar patterns of rehabilitated individuals conducting circuitous loops and non-directional movement patterns has also been reported for rehabilitated loggerhead turtles released in the Mediterranean (Cardona et al. 2012). Moreover, such behavior has not been previously reported from wild-caught loggerhead turtles on the eastern coast of the USA, which generally exhibited more direct migrations between relatively small coastal foraging areas (e.g. Morreale \& Standora 2005, Hawkes et al. 2011). This suggests that some rehabilitated turtles, at least in the short-term, may have an impaired navigational capacity even if they eventually resume normal migratory behavior.

Another interesting observation is that the migratory behavior of each of the 3 turtle species in this study was notably similar. All species exhibited overlap in their movements and occupied both the coastal waters of the eastern coast of the USA as well as the oceanic waters of the Gulf Stream (Fig. 1). The SST data, however, suggested that these turtles were inhabiting waters of different temperatures. Specifically, green turtles occupied warmer waters than Kemp's ridley turtles, which in turn occupied warmer waters than loggerhead turtles (Fig. 4). Such trends reflect the known differences in susceptibility of each species to cold-stunning, with threshold temperatures being highest for green turtles, intermediate for Kemp's ridley turtles, and lowest for loggerhead turtles (Morreale et al. 1992, Still et al. 2005, Roberts et al. 2014). Thus, despite the seemingly similar movement patterns for these 3 species, there may be subtle differences influencing the thermal conditions experienced by each species. To elucidate these differences would likely require larger sample sizes and more accurate satellite transmitters (e.g. GPS transmitters).

\subsection{Do rehabilitated sea turtles resume typical diving behaviors?}

The dive data relayed by the 16 turtles with Mk10 or SPLASH transmitters revealed that these animals began diving immediately upon release and contin- 
ued diving for their entire tracking duration. The diving patterns exhibited by each species were similar, with each species predominantly diving to shallow depths between 0 and $10 \mathrm{~m}$, as is commonly observed in wild-caught juvenile sea turtles (Southwood et al. 2003, Howell et al. 2010). Nevertheless, there were some important inter-specific differences. In coastal habitats, green turtles on average dove to the shallowest depths, Kemp's ridley turtles dove to intermediate depths, and loggerhead turtles dove the deepest. Such patterns could be attributable to differences in the foraging strategies of each species. Juveniles green turtles primarily feed on seagrass and algae (Williams et al. 2014, Gillis et al. 2018), which is largely found at depths of $<5 \mathrm{~m}$ in LIS (Koch \& Beer 1996) and generally at depth of $<20 \mathrm{~m}$ worldwide (Duarte 1991). In contrast, Kemp's ridley turtles and loggerheads feed largely on invertebrates (Burke et al. 1993), which can be found at a wider range of depths than seagrass. The slightly shallower diving preferences of Kemp's ridley turtles may also reflect that this species tends to prey more on pelagic species while loggerhead turtles focus on benthic species (Burke et al. 1994).

We recorded distinct migratory behaviors in each species, with some turtles migrating to coastal habitats and others into the Gulf Stream, and this data also allowed us to compare the diving behaviors of turtles in coastal and oceanic habitats. Interestingly, the dive behavior of juvenile loggerhead turtles remained notably similar regardless of habitat, with around $60 \%$ of dives occurring between 0 and $10 \mathrm{~m}$. It may be surprising that an animal would retain similar diving patterns when switching from benthic to pelagic foraging strategies; however, juvenile loggerhead turtles in the oceanic waters of the east Atlantic also exhibit similar diving patterns, with $60-$ $80 \%$ of their dives between 0 and $10 \mathrm{~m}$ (Freitas et al. 2018). In contrast, those Kemp's ridley turtles that migrated into offshore waters exhibited different diving patterns than their pelagic counterparts. Coastal Kemp's ridley turtles dove to depths between 0 and $10 \mathrm{~m}$ for $77 \%$ of all dives, whereas for oceanic individuals this number was over $99 \%$. Such values were similar to the diving patterns of juvenile Kemp's ridley turtles tracked in the Gulf of Mexico, which spent over $90 \%$ of their time in the top $1 \mathrm{~m}$ of the water column (Witherington et al. 2012).

Overall, the diving patterns of rehabilitated turtles suggest that the time spent in captivity does not affect their diving behavior in any observable way. Once released, they exhibited similar diving behaviors to wild-caught counterparts, which suggests that these animals are able to find and exploit conventional food sources. In addition, all species conducted dives, albeit infrequently, that exceeded $100 \mathrm{~m}$, indicating that rehabilitated animals retain the capacity for deep diving.

\subsection{Conservation implications}

Most turtles that were released in LIS following rehabilitation migrated away from local waters before temperatures dropped below the threshold for cold-stunning. After leaving Long Island, these animals resumed long-distance migratory movements and diving behaviors that were comparable to nonrehabilitated, wild-caught individuals. These results indicate that rehabilitated turtles can survive, for at least several months, after being re-introduced into the wild and quickly resume typical migratory and diving behaviors. This demonstrates that wildlife rehabilitation programs are effective tools for animal rescue; however, this does not conclusively indicate that these programs are effective tools for species conservation. Proving this would require evidence that rehabilitated turtles not only migrate and dive as normal but also were reincorporated into natural breeding populations. As the juvenile turtles in this study may still require years to decades until they reach sexual maturity, it would be almost impossible to use satellite telemetry to assess if these specific individuals eventually bred with other wild turtles. A more effective way to assess this question may therefore be to use mark-recapture technologies. Several studies have already attempted this technique, however, the portion of individuals of turtles that are encountered nesting after being released is generally far below $1 \%$ (Flint et al. 2017, Innis et al. 2019a). Whether the low number of resightings reflects that only a small proportion of rehabilitated sea turtles reintegrate into wild populations or is due to undersampling is still to be determined. Thus, while we are still unable to unequivocally assess the value of sea turtle rehabilitation efforts for supporting wild populations, our finding that rehabilitated turtles tend to resume typical migratory and diving behaviors provides some indirect support that these animals may also resume typical breeding behaviors.

Acknowledgements. We thank the staff and volunteers of the Sea Turtle Stranding and Salvage Network, The New York Marine Rescue Center (previously known as the Riverhead Foundation for Marine Research and Preservation), the New York Department of Environmental Conservation, 
local Marine Patrol, and the public who gave countless hours patrolling these beaches looking for stranded sea turtles. Funding was provided by the CT State Department of Education Inter-district program to Danbury Public Schools and the NOAA National Marine Fisheries Service, Office of Education award through its NESDIS and New England BWET Program to T.P. (\#NA10NES4400005 and \#16NMF 0080003). Research was conducted under WCSU IACUC Protocol 112-02 and USFWS permit \#TE-697823 and \#TEO 1150C-2 to R.A.D.

\section{LITERATURE CITED}

Burke VJ, Standora EA, Morreale SJ (1991) Factors affecting strandings of cold-stunned juvenile Kemp's ridley and loggerhead sea turtles in Long Island, New York. Copeia 1991:1136-1138

Burke VJ, Standora EA, Morreale SJ (1993) Diet of juvenile Kemp's ridley and loggerhead sea turtles from Long Island, New York. Copeia 1993:1176-1180

Burke VJ, Morreale SJ, Standora EA (1994) Diet of the Kemp's ridley sea turtle, Lepidochelys kempii, in New York waters. Fish Bull 92:26-32

Caillouet CW Jr, Putman NF, Shaver DJ, Valverde RA and others (2016) A call for evaluation of the contribution made by rescue, resuscitation, rehabilitation, and release translocations to Kemp's ridley sea turtle (Lepidochelys kempii) population recovery. Herpetol Conserv Biol 11: 486-496

Cardona L, Fernández G, Revelles M, Aguilar A (2012) Readaptation to the wild of rehabilitated loggerhead sea turtles (Caretta caretta) assessed by satellite telemetry. Aquat Conserv 22:104-112

Coyne M, Godfrey M, Godley B, Lay K (2008) Hard shell sea turtle PTT attachment protocol. www.seaturtle.org/ documents/PTT_Attachment_Protocol.pdf

₹ Duarte CM (1991) Seagrass depth limits. Aquat Bot 40: 363-377

Feck AD, Hamann M (2013) Effect of sea turtle rehabilitation centres in Queensland, Australia, on people's perceptions of conservation. Endang Species Res 20:153-165

Flint J, Flint M, Limpus CJ, Mills P (2017) Status of marine turtle rehabilitation in Queensland. PeerJ 5:e3132

* Freitas C, Caldeira R, Reis J, Dellinger T (2018) Foraging behavior of juvenile loggerhead sea turtles in the open ocean: from Lévy exploration to area-restricted search. Mar Ecol Prog Ser 595:203-215

Gillis AJ, Ceriani SA, Seminoff JA, Fuentes MM (2018) Foraging ecology and diet selection of juvenile green turtles in the Bahamas: insights from stable isotope analysis and prey mapping. Mar Ecol Prog Ser 599:225-238

* Gitschlag GR (1996) Migration and diving behavior of Kemp's ridley (Garman) sea turtles along the US southeastern Atlantic coast. J Exp Mar Biol Ecol 205:115-135

* Guy AJ, Curnoe D, Banks PB (2013) A survey of current mammal rehabilitation and release practices. Biodivers Conserv 22:825-837

Hawkes LA, Broderick AC, Coyne MS, Godfrey MH, Godley BJ (2007) Only some like it hot-quantifying the environmental niche of the loggerhead sea turtle. Divers Distrib 13:447-457

Hawkes LA, Witt MJ, Broderick AC, Coker JW and others (2011) Home on the range: spatial ecology of loggerhead turtles in Atlantic waters of the USA. Divers Distrib 17: $624-640$
Hochscheid S (2014) Why we mind sea turtles' underwater business: a review on the study of diving behavior. J Exp Mar Biol Ecol 450:118-136

*Howell EA, Dutton PH, Polovina JJ, Bailey H, Parker DM, Balazs GH (2010) Oceanographic influences on the dive behavior of juvenile loggerhead turtles (Caretta caretta) in the North Pacific Ocean. Mar Biol 157:1011-1026

* Innis C, Nyaoke AC, Williams CR, Dunnigan B and others (2009) Pathologic and parasitologic findings of coldstunned Kemp's ridley sea turtles (Lepidochelys kempii) stranded on Cape Cod, Massachusetts, 2001-2006. J Wildl Dis 45:594-610

Innis CJ, Finn S, Kennedy A, Burgess E, Norton T, Manire CA, Harms C (2019a) A summary of sea turtles released from rescue and rehabilitation programs in the United States, with observations on re-encounters. Chelonian Conserv Biol 18:3-9

* Innis CJ, McGowan JP, Burgess EA (2019b) Cold-stunned loggerhead sea turtles (Caretta caretta): initial vs. convalescent physiologic status and physiologic findings associated with death. J Herpetological Med Surg 29:105-112

Jonsen ID, Basson M, Bestley S, Bravington MV and others (2013) State-space models for bio-loggers: a methodological road map. Deep Sea Res II 88-89:34-46

*Keller KA, Innis CJ, Tlusty MF, Kennedy AE, Bean SB, Cavin JM, Merigo C (2012) Metabolic and respiratory derangements associated with death in cold-stunned Kemp's ridley turtles (Lepidochelys kempii): 32 cases (2005-2009). J Am Vet Med Assoc 240:317-323

Koch EW, Beer S (1996) Tides, light and the distribution of Zostera marina in Long Island Sound, USA. Aquat Bot 53:97-107

*McClellan CM, Read AJ (2007) Complexity and variation in loggerhead sea turtle life history. Biol Lett 3:592-594

* Mestre F, Bragança MP, Nunes A, dos Santos ME (2014) Satellite tracking of sea turtles released after prolonged captivity periods. Mar Biol Res 10:996-1006

Mignucci-Giannoni AA (1998) Marine mammal captivity in the northeastern Caribbean, with notes on the rehabilitation of stranded whales, dolphins and manatees. Caribb J Sci 34:191-203

Moore M, Early G, Touhey K, Barco S, Gulland F, Wells R (2007) Rehabilitation and release of marine mammals in the United States: risks and benefits. Mar Mamm Sci 23: $731-750$

Morreale SJ, Standora EA (2005) Western North Atlantic waters: crucial developmental habitat for Kemp's ridley and loggerhead sea turtles. Chelonian Conserv Biol 4: 872-882

*Morreale SJ, Meylan AB, Sadove SS, Standora EA (1992) Annual occurrence and winter mortality of marine turtles in New York waters. J Herpetol 26:301-308

* Roberts K, Collins J, Paxton CH, Hardy R, Downs J (2014) Weather patterns associated with green turtle hypothermic stunning events in St. Joseph Bay and Mosquito Lagoon, Florida. Phys Geogr 35:134-150

Kobinson DP, Jabado RW, Rohner CA, Pierce SJ, Hyland KP, Baverstock WR (2017) Satellite tagging of rehabilitated green sea turtles Chelonia mydas from the United Arab Emirates, including the longest tracked journey for the species. PLOS ONE 12:e0184286

Shaver DJ, Tissot PE, Streich MM, Walker JS and others (2017) Hypothermic stunning of green sea turtles in a western Gulf of Mexico foraging habitat. PLOS ONE 12: e0173920 
Southwood AL, Reina RD, Jones VS, Jones DR (2003) Seasonal diving patterns and body temperatures of juvenile green turtles at Heron Island, Australia. Can J Zool 81: 1014-1024

Still BM, Griffin CR, Prescott P (2005) Climatic and oceanographic factors affecting daily patterns of juvenile sea turtle cold-stunning in Cape Cod Bay, Massachusetts. Chelonian Conserv Biol 4:883-890

Tribe A, Booth R (2003) Assessing the role of zoos in wildlife conservation. Hum Dimens Wildl 8:65-74

Ullmann J, Stachowitsch M (2015) A critical review of the Mediterranean sea turtle rescue network: a web looking for a weaver. Nat Conserv 10:45-69

Vogelnest L (2008) Veterinary considerations for the rescue, treatment, rehabilitation and release of wildlife. In: Vogelnest L, Woods R (eds) Medicine of Australian Mammals. CSIRO Publishing, Collingwood, p 1-2

Williams NC, Bjorndal KA, Lamont MM, Carthy RR (2014) Winter diets of immature green turtles (Chelonia mydas)

Editorial responsibility: Matthew Godfrey,

Beaufort, North Carolina, USA;

Christine Paetzold, Braubach, Germany on a northern feeding ground: integrating stomach contents and stable isotope analyses. Estuaries Coasts 37 : 986-994

* Williard AS, Hall AG, Fujisaki I, McNeill JB (2017) Oceanic overwintering in juvenile green turtles Chelonia mydas from a temperate latitude foraging ground. Mar Ecol Prog Ser 564:235-240

*Winton MV, Fay G, Haas HL, Arendt M and others (2018) Estimating the distribution and relative density of satellite-tagged loggerhead sea turtles using geostatistical mixed effects models. Mar Ecol Prog Ser 586: $217-232$

*Witherington BE, Ehrhart LM (1989) Hypothermic stunning and mortality of marine turtles in the Indian River Lagoon System, Florida. Copeia 1989:696-703

* Witherington B, Hirama S, Hardy R (2012) Young sea turtles of the pelagic Sargassum-dominated drift community: habitat use, population density, and threats. Mar Ecol Prog Ser 463:1-22

Submitted: March 11, 2020; Accepted: July 21, 2020 Proofs received from author(s): September 19, 2020 